\title{
Waste to Energy Financial Model Design Based on Resident Participation
}

\author{
Farizal $^{1}$, Nadya Amalin ${ }^{1}$ and Amar Rachman ${ }^{1}$
}

\begin{abstract}
This study designed a financial model for utilizing municipal solid waste (MSW) to generate energy based on resident participation. This effort is crucial since in many cases a government has some competing programs to be funded on its limited money. This makes a public project does not receipt enough funding to run the best option available or even the project sometime has not funded at all. On the other side, regulation and social responsibility factors inhibit private sector to invest their money on it. Based on willingness to pay research conducted at the City of Depok, it was shown that the residents are willing to spend their money to get a better MSW treatment through funding a Sustainable Modular Landfill Gas Plant project. A financial model developed for the project showed that the project is feasible. The project gave a positive net present value and internal rate of return greater than the average Indonesian bank interest rate; that is $13.87 \%$ for no electricity discounts scenario and $13.73 \%$ for electricity discount scenario. Further analysis showed that the minimum number of resident to participate on the project are $7 \%$ and $51 \%$ of the total Depok household, respectively.
\end{abstract}

Keywords: Financial model, waste to energy, landfill gas plant project, net present value, internal rate of return.

\section{Introduction}

Economic growth and population increment will directly affect energy consumption (Tiess and Mujiyanto, 2013). Indonesian population increases from 237.6 million in 2010 to 260 million in 2017 (Indonesia Investments, 2019). In the last ten years (2003-2013), energy consumption in Indonesia has increased from 79 million TOE to 134 million TOE which means it grows on average $5.5 \%$ per year (DEN, 2014). Electricity, as a form of energy, consumption continues to increase every year with an average rate about $7.2 \%$ per year. However, electricity power generation capacity grow only on average by $5.1 \%$ per year (DEN, 2014). This fact shows there is a shortage of electricity in Indonesia. Meanwhile, another problem faced by Indonesian government is municipal solid waste (MSW) management. MSW will continue to be produced as long as human beings exist. According to Sudrajat (2007) the waste volume produced is proportional to the number of the population. Lack of management of liquid and solid waste management system in Indonesia, could pose many significant threats to human health and the environment.

Indonesian government has made a target that energy mix in 2015 will consist of $25 \%$ of renewable energy and 75\% of fossil energy. Whereas in 2010 the target of using renewable energy as the main energy source is only 5\% (EMR, 2013). One of potential bioenergy technology in Indonesia is biogas. The use of bioenergy technology can improve human welfare because it can improve the city sanitation, reduce smoke, better lighting, and job creation (Amiguna and Blottnitz, 2009). Bioenergy can also improve the 
quality of the environment because it can improve water quality, conserve resources, especially trees, and reducing green house gas (GHG) emissions (Amigun et al, 2008).

One possible way to treat MSW that can reduce environmental impact significantly and simultaneously provide benefit in the form of energy is developing landfill gas plant; commonly referred as landfill gas, LFG. According to Yazdani et al (2006), methane gas $\left(\mathrm{CH}_{4}\right)$ and carbon dioxide $\left(\mathrm{CO}_{2}\right)$ are two dominant gases produced at the landfill as the waste decomposed. It is approximated that $45-60 \%$ of the gases produced are methane and $40-60 \%$ are carbon dioxide. These two gases are GHG sources. Fortunately, methane gas can be used as feed stock to generate electricity. According Tasri and Susilawati (2014), applying landfill gas technology is a proper way for treating MSW in Indonesia.

Economic analysis for waste to energy (WtE) program has been widely applied in some countries and also with variety of existing technologies. WtE economic analysis by comparing two technologies, inceneration and landfill gas technology, for processing MSW in Thailand conducted by Menikpura et al (2014). Comparison of the two WtE technologies also have been done by Dong et al (2014) by comparing indicators of environmental, economic, and energy. Xin-gang et al (2015) conducted an economic analysis by calculating investment cost as the feasibility indicator of investment in WtE inceneration technology. While Johari et al (2012) analyzed the economic benefits and environment of landfill gas in Malaysia. Inceneration indeed can generate more electricity than the landfill gas plant, but it also requires a greater operational cost and gives by products of ash that can create air pollution (Menikpura et al, 2014; Dong et al, 2014; Xin-gang et al, 2015).

Even tough utilization of LFG is one of best solution for a better waste management and simultaneously solves the energy problem in Indonesia. But due to one reason or another, the government does not eagerly utilize this approach to its around four hundred landfills (Trisyanti and Helmy, 2015). On the other side, regulation and social consideration are not allowed private investors either. However, Farizal et al (2019) showed an alternative way to fund LFG. On their research, based on Willingness to Pay (WTP) survey they developed, at the City of Depok, Depok residents were willing to donate their money to get a better MSW management through constructing a sustainable landfill gas plant (SLFG) project at their district. This study developed financial model based on resident participation of the project, showed the reliability of the funding source and calculated the minimum resident participation required to make sure the project run appropriately.

\section{Methodology}

Since sources, including money, are not unlimited, every project should be analyzed before implemented. Study to analyze whether a project is attracted and profitable is economic feasibility study. For the purposes, methods to evaluate a project worthiness are Net Present Value, Internal Rate of Return, External Rate of Return, and Payback Period (Canada, et al 2005). Among the methods, due to its simplicity, NPV is the most popular one to used. 
Net Present Value Analysis. This analysis calculates net revenues of the whole life of the project and then equates the value to its present value. A project is considered profitable and worth to do if the NPV is greater than 0 (or positive). If there are several competing alternative investment projects, the best alternative is the one with the highest NPV. NPV is calculated using the following formula:

$\mathrm{NPV}=I+\sum_{n=1}^{n}\left(\frac{A n}{L(1+r)^{n}}+\frac{V n}{L(1+r)^{n}}\right)$

Where $I$ is investment, $r$ is rate of return, $A n$ is cash flow/proceed, $n$ is time when the cash flow occurs, and $V n$ is salvage value of investments at the end of economic period

Internal Rate of Return Analysis. Instead of calculating the NPV in the term of money earned, IRR basically calculates the percentage of profit of the project. A project is accepted if its IRR is greater than MARR (Minimum Attractive Rate of Return) set by the company. MARR is usually set a bit higher than the interest the company pay to the lender for financing their project. IRR can also be interpreted as the discount rate that produces zero NPV as shown at the formula below.

$\sum_{n=1}^{n} P W_{n}(p o s)-P W_{n}(n e g)=0$

Sensitivity Analysis. The calculation using one or more methods mentioned above uses data that most of the time are estimated (or predicted). in reality, assumptions and estimations are not free from errors or mistakes. A project is also facing risks that sometimes not seen in advance. Sensitivity analysis is the way to check how a factor(s), for instance cost, profit, project life time, influence the outcome of the calculation. Sensitivity analysis gives an interval outcome of the calculations, instead of a single number, so project decision maker will have the minimum (the least) and the maximum results of the project.

\section{Sustainable Landfill Gas Plant Model}

Landfill gas plant (LFG) is a facility that collects methane gas produced from decomposition of MSW dumped at a landfill. LFG uses the collected gas to generate electricity. LFG facility is consisted of gas collection system, gas treatment system, and electricity generation system. Scheme of a typical LFG is shown in Figure 1.

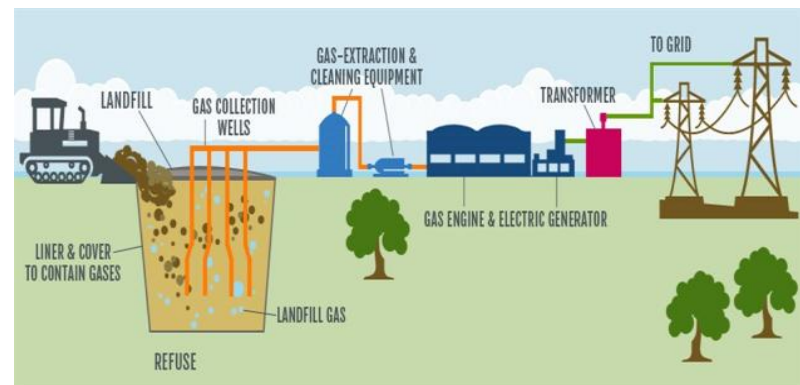

Figure. 1. Landfill Gas Plant Scheme (US EPA, 2010)

Unlike ordinary landfill that collects MSW for a certain period of time and closed when its capacity reached a maximum point. Proposed LFG model on this study is designed to 
be a sustainable facility in the sense that the landfill will be used to dump MSW and generate electricity forever. Even thought the plant life time is around 20 years (US EPA, 2015), but the LFG itself will never be closed. Once a plant is about to be decommissioned, another LFG is erected as a new plant at the adjacent area and start to produce electricity. This practice is repeated until a newer landfill opens at the first landfill site and a newer LFG erected. Sustainable landfill plant (SLFG) model was developed by Ardiansyah (2014). Landfill gas plant (LFG) will be used as a power plant with gas engine as its power generation. The selection of gas engine as power generation is because for generating $1 \mathrm{MW}$ electricity, needs an input approximately 0.4 to 1.6 millions $\mathrm{ft}^{3}$ per day with a composition of $50 \%$ methane. As addition, gas engine is commonly used as power generation for LFG, especially in America (US EPA, 2015).

Landfill gas processing will be done in a sustainable manner in which land use of landfill will increase at a time until it settles. MSW will be collected during the next three years and one year used for the construction of power generation facilities. Gasses production will be started in the first year until the $25^{\text {th }}$ year. During the production, the landfill continues to open up a new landfill of the same size every three years. Table plan activities for SLFG development model are shown in Table 1.

Table 1. Activities Plan of Sustainable Landfill Gas Plant

\begin{tabular}{|c|c|c|c|c|c|c|c|c|c|c|c|c|c|c|c|c|c|c|c|c|c|c|c|c|c|c|c|c|c|c|}
\hline \multirow{2}{*}{ Aktivitas } & \multicolumn{30}{|c|}{ Time (Year) } \\
\hline & -4 & -3 & -2 & -1 & 0 & 1 & 2 & 3 & 4 & 5 & 6 & 7 & 8 & 9 & 10 & 11 & 12 & 13 & 14 & 15 & 16 & 17 & 18 & 19 & 20 & 21 & 22 & 23 & 24 & 25 \\
\hline Landfill Preparation & A & & & & & & c & & & & & & & & & $\mathrm{F}$ & & & G & & & $\mathrm{H}$ & & & A & & & & & \\
\hline \multicolumn{31}{|l|}{ Piling Up Waste } \\
\hline \multicolumn{31}{|l|}{ Landfill Gas Construction } \\
\hline LFG Production & & & & & & & & & & & & & & & & & & & & & & & & & & & & & & \\
\hline
\end{tabular}

In addition, it is assumed in this study that a landfill will only produce methane for 15 years, although actually the anaerobic reaction of MSW produces methane landfill within 20 years period (US EPA, 2015). This assumption was done because according to the Nevada Department of Taxation (2010) and US EPA (2015), the age of the gas collection equipment has a useful life of 15 years. Thus, the model Landfill gas will be made with the assumption that a landfill cell will contribute to generate gas to be processed into electricity for 15 years. Meanwhile, at the age of 20 years, a landfill cell can be excavated to be stockpiled garbage again. Waste buried in landfills will undergo anaerobic process and will shrink by $25 \%$ from the previous volume of waste mound after 20 years (US EPA, 2015).

The calculation of estimated methane gas production and electricity potential will use US EPA model; i.e Landgem v-302 that already used in many LFG projects calculation in America. For applying SLFG model, the model is implemented to MSW management at the City of Depok. A suburban of Jakarta that just has one landfill at Cipayung site (Farizal and Tammarar, 2018). It is estimated that the average electricity generated at Cipayung was 5.62 MW. For this purpose, the ideal gas engine capacity to used is $6 \mathrm{MW}$. Pattern of methane gas produced at landfill gas from year- 0 production to year 25 is shown in Figure 2. 


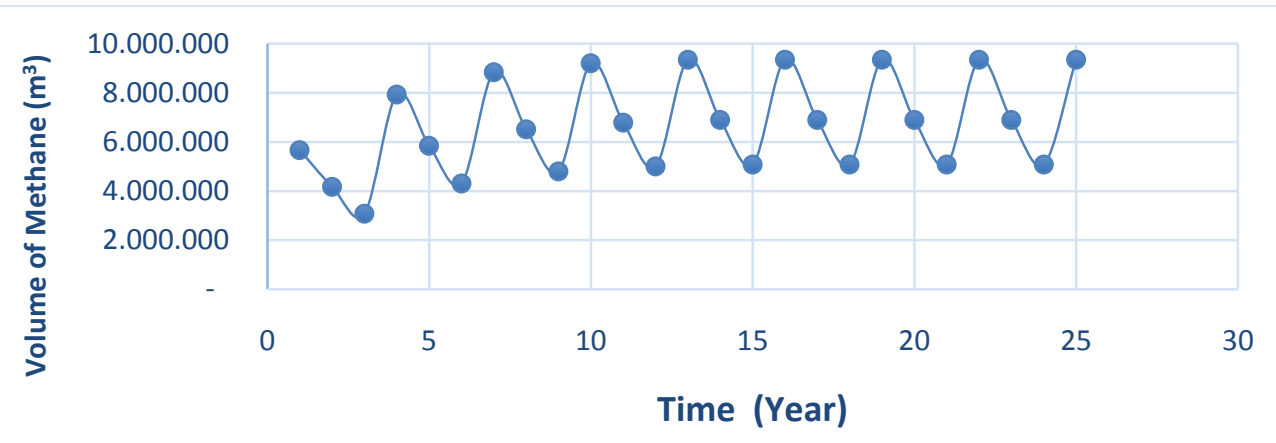

Figure 2. Sustainable Landfill Gas Methane Production Model

Compare to ordinary LFG, sustainable landfill gas plant offers some advantage such as producing a more stable and more amount of methane gas and the facility is sustainable. However, SLFG undoubtedly needs more funding than the ordinary one. The cost will consist of investment costs, and operation and maintenance costs. The initial investment cost required in development LFG consists of landfill gas system components and installation costs. Projected investment costs needed for LFG in the City of Depok are shown in Table 2. Meanwhile, the operation and maintenance costs will consist of labor costs, utilities' costs, and maintenance costs. As shown in Table 1, the investments are made gradually for each cell of the landfill. Each year will be required different operational costs until the 13th year. In the year 13 of production, there will be 5 landfill cells operating annually. Total annual operation cost of 5 active landfill cells is summarized in Table 3.

Table 2. Total Investment Cost of 8 Cells of Sustainable Landfill Gas Plant

\begin{tabular}{|l|l|l|l|l|}
\hline Component & Quantity & Unit Price (IDR) & Total Price (IDR) & Reference \\
\hline Land Preparation $\left(\mathrm{m}^{3}\right)$ & $10,080,000$ & 27,330 & $275,486,803,200$ & KPU (2012) \\
\hline Gas Collection \& Flare system (Acre) & 124.54 & $351,188,907$ & $43,737,389,572$ & EPA (2015) \\
\hline Treatment system $\left(\mathrm{ft}^{3} / \mathrm{min}\right)$ & 926.43 & $15,149,325$ & $14,034,716,554$ & EPA (2015) \\
\hline Electricity generation $(\mathrm{kW})$ & 6,000 & 999,205 & $5,995,231,200$ & EPA (2015) \\
\hline Geomembran capping and Instalation $\left(\mathrm{m}^{2}\right)$ & 100,000 & 60,798 & $61,284,585,600$ & Duffy (2016) \\
\hline Electricity Power Distribution (Unit) & 1 & $2,003,774,360$ & $2,003,774,360$ & $\begin{array}{l}\text { Maxpower } \\
\text { Indonesia }\end{array}$ \\
\hline Leachate removal system (Acre) & 124.54 & $105,736,000$ & $13,168,458,717$ & Duffy (2016) \\
\hline Total & & $\mathbf{4 1 5 , 7 1 0 , 9 5 9 , 2 0 3}$ & \\
\hline
\end{tabular}

Table 3. Operations \& Maintenance Costs of 5 Active Landfill Cells per Year

\begin{tabular}{|l|c|c|c|c|}
\hline Component & Quantity & Unit Price (IDR) & Total Price (IDR) & Reference \\
\hline Gas Collection \& Flare system (Acre) & 124.54 & $980,535,782$ & $76,323,017,701$ & EPA (2015) \\
\hline Treatment system (ft $3 / \mathrm{min})$ & 926.43 & $1,790,375$ & $1,658,648,320$ & EPA (2015) \\
\hline Electricity generation (kW) & 6,000 & $2,478,981$ & $14,873,883,120$ & EPA (2015) \\
\hline Leachate removal system (Acre) & 124.54 & $15,660,400$ & $1,218,975,417$ & Duffy (2016) \\
\hline Operator \& staff (person) & 43 & $32,460,000$ & $1,395,780,000$ & Ardiansyah (2014) \\
\hline Supervisor (person) & 1 & $42,198,000$ & $42,198,000$ & Ardiansyah (2014) \\
\hline Waste pile up cost & & & $1,345,508,750$ & DKP (2015) \\
\hline Waste Collection cost & & & $17,759,895,625$ & DKP (2015) \\
\hline Total & & $\mathbf{1 1 4 , 6 1 7 , 9 0 6 , 9 3 4}$ & \\
\hline
\end{tabular}


SLFG Cash Flow. Cash flow indicates of the amount of cash spent and earned in the future. It provides useful information report to users in evaluating the changes of company's net worth. Cash flow projections in this study will be made with the calculation of revenues and costs incurred during the life time of SLFG, which is 25 years. Cash flow scenarios were created with some conditions described below:

First, based on SLFG model described in Table 1, the construction of a landfill cell consists of the cost of land excavation, investment and installations of capping on the base and the surface of landfill, as well as the installation of leachate treatment system. The investment of land excavation and the installation of capping and leachate treatment system also occurred in year $2,5,8,11,14,17$. While the excavations in the 20 th year will just consist of land excavation cost which has shrunk by $25 \%$. Meanwhile, the installation of gas collection system occurred in year 3, 6, 9, 12, 15, 18, 21.

Second, depreciation used in this study is based on Indonesia Ministry of Finance Regulation No. 21/PMK.01/2010 about Taxation and Incentives for Renewable Energy Sources Utilization Activities. The depreciation model will be Straight Line Model at $12.5 \%$ of the investment cost of equipments. It is applicable only for the first 8 years of the equipments being installed.

Third, gas collection system equipments at a landfill cell operate only for 15 years. From the year 15th until 20th, a landfill cell will not generate gasses since the lifetime of the gas collection equipments has assumed already finished in 15th year. Thus, operating costs are calculated based on the number of landfill cells and the equipments currently active in certain year.

Fourth, on the year 16th there will be an investment again for buying new gas engines and new treatment systems.

Fifth, according to PMK No. 21/PMK.011/2010 about Taxation and Customs Facilities for Renewable Energy Utilization Activities, taxable income in the first 6 years of operation get $30 \%$ deduction of net income; it is charged $5 \%$ per year for 6 years. Meanwhile, the income tax is $25 \%$.

Sixth, the cost of land acquisition to build a landfill gas facility will be assumed provided by City government as according to Presidential Decree Regulation No. 18/2016 about The Accelerated Development of Waste To Energy.

Seventh, this study will be done in 2 scenarios of calculation.

a. Cash flow scenario without electricity discount offer.

- Operational cost is the cost of the equipment operated actively in certain year.

- The cash in flow consists of electricity sales (the price is according to PerMen No. 44/2015), Carbon Development Mechanism (CDM) incentives, and resident funding participations from the $4^{\text {th }}$ parts of WTP questionnaire survey results (Farizal, et al 2019).

b. Cash flow scenario with electricity discount offer.

- Operational cost consists of the cost of the equipment operated actively in certain year and the electricity discount for the participate residents (Farizal, et al 2019).

- The cash in flow consists of electricity sales (according to PerMen No. 44/2015), CDM incentives, and resident funding contributions from the $5^{\text {th }}$ parts of WTP questionnaire survey results. 


\section{Results and Discussion}

\subsection{Economic Feasibility Analysis}

Based on the assumptions and data described earlier, a financial model has been developed with Excel. Financial worthiness calculation results of Sustainable Landfill Gas Plant (SLFG) of the City of Depok are summarized in Table 4.

Table 4. Feasibility Indicator of SLFG Project in the City of Depok

\begin{tabular}{|c|c|c|}
\hline $\begin{array}{c}\text { Feasibility } \\
\text { Parameter }\end{array}$ & $\begin{array}{c}\text { Without electricity } \\
\text { discounts offer }\end{array}$ & $\begin{array}{c}\text { With electricity } \\
\text { discounts offer }\end{array}$ \\
\hline NPV (IDR) & $2,175,023,689,760$ & $1,780,943,573,848$ \\
\hline IRR $(\%)$ & 13.91 & 13.77 \\
\hline
\end{tabular}

Table 4 shows that both scenarios of SLFG have a positive NPV at the bank rate of on average is $11 \%$. From the IRR view, the rates are higher than MARR, i.e. $13.91 \%$ and $13.77 \%$ for without and with discount, respectively. These results indicate that the residence based SLFG is economically acceptable in both cash flow scenarios. From the Indonesian Financial Statistics (BI, 2016), MARR from 2010 to 2016 is between 9.86\% $13,58 \%$.

Furthermore, Table 4 shows that both results, the NPV value and IRR from scenario with electricity discount offer are less than scenario without electricity discounts offer. Although the nominals of WTP with discount offer scenario are significantly higher than the nominals of WTP without electricity discount offer. This is due to the electricity discount scenario has extra operational costs per year; i.e. electricity discount given to to $88 \%$ of Depok citizens who agreed to participate. However, the NPV value is still large enough as $1,780,943,573,848$ IDR. Besides that, the implementation of the scenario will give economic benefit to the participants, in the form of electricity discounts, that in turn will drive more Depok resident to participate and to donate.

\subsection{Sensitivity Analysis}

This sensitivity analysis is used to determine the effect of changes in the number of participants in the funding program towards the NPV value. The results are displayed on Figures 3 and 4.

Figure 3 shows that in the scenario without a discount, NPV generated by the project is linear to the number of participant willing to pay. This means that the more the participants', the greater the NPV. The graph also shows that when the number of participants is reduced even by $90 \%$, the NPV is still positive. The NPV will be negative with the amount of $163,397,319,787$ IDR if the participant withdrawal completely from the program. Figure 3 shows that the cut off number of participant to get the NPV zero is $7 \%$ of the total household. So, as long as the funding participant is greater than $7 \%$ this scenario is still attractive to do. 


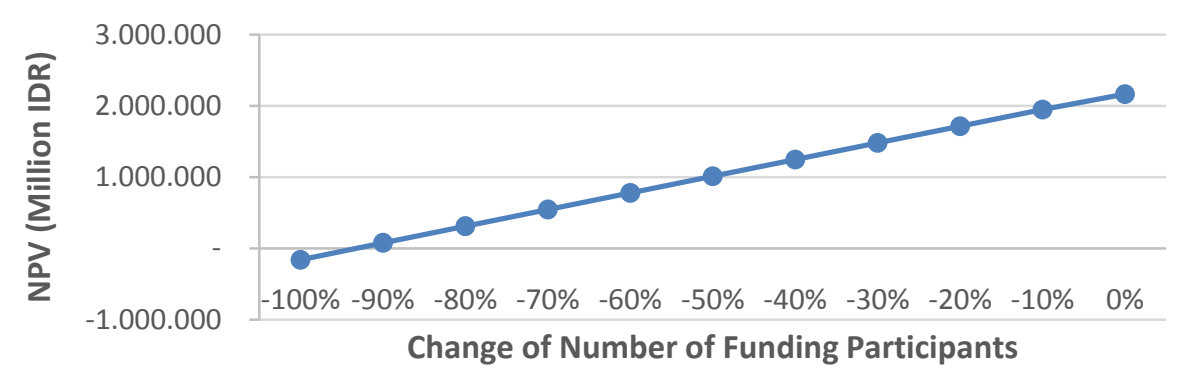

Figure 3. Change of Number of Funding Participants to NPV on Without Electricity Discount Offer Scenario

Figure 4 is for the scenario with electricity discount offer. The chart says that if the number of participant is reduced by $50 \%$, the NPV will be negative with value of 33,003,959,977 IDR. The discounts offered cause the operational costs much higher than the previous model. Figure 6 shows when the number of participants was reduced by $49 \%$, or only $51 \%$ participants the NPV will be 0 . This means this scenario must keep the number of participant slightly more than $51 \%$ in order to be profitable.
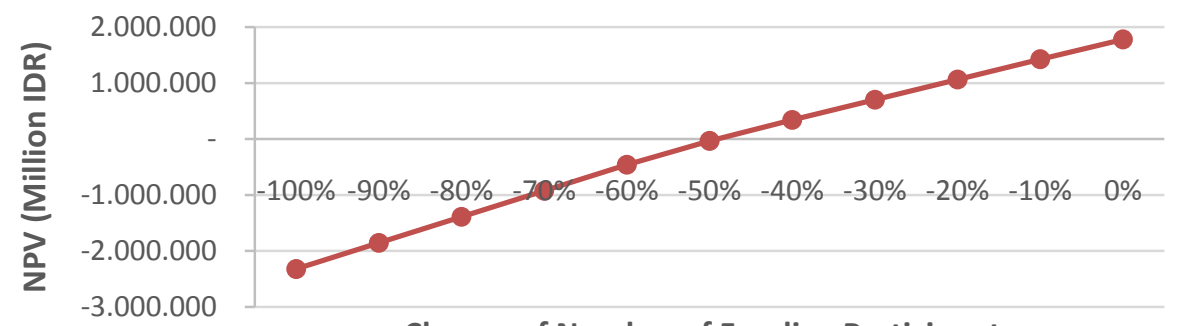

Change of Number of Funding Participants

Figure 4.Change of Number of Funding Participants Towards NPV on With Electricity Discount Offer Scenario

The composition of minimum number of participants for without discount scenario and with discount scenario is shown in Table 5. The table shows that the biggest number of participant belongs to the group with the lowest amount of contribution; i.e. 80,000 IDR per month.

Table 5. Composition of the Minimum Number of Funding Participants

\begin{tabular}{|c|c|c|c|}
\hline \multicolumn{2}{|c|}{ Without electricity discounts } & \multicolumn{2}{c|}{ With electricity discounts } \\
\hline $\begin{array}{c}\text { Value (IDR) } \\
\text { /Month }\end{array}$ & Participants (\%) & $\begin{array}{c}\text { Value (IDR) } \\
\text { /Month }\end{array}$ & Participants (\%) \\
\hline 20,000 & 1,3 & 80,000 & 33.2 \\
\hline 50,000 & 3,5 & 100,000 & 10.6 \\
\hline 80,000 & 0,8 & 150,000 & 4.4 \\
\hline 100,000 & 0,9 & 200,000 & 2.7 \\
\hline 200,000 & 0,5 & & $51 \%$ \\
\hline Total & $7 \%$ & Total & \\
\hline
\end{tabular}


The impact of changing the value of the WTP to the NPV produces a similar results as the impact of changing the number of participants to the NPV. Composition of minimum value and its percentage is shown in Table 6. The table indicates that the lowest and highest contribution for without discount scenario can reduce to 1,050 IDR and 14,000 IDR, respectively to make the NPV still positive. While for with discount scenario, the lowest and the highest contribution just can reduce close to half of the original contribution in order to keep the NPV positive. The lowest and the highest donation can go down to 40,800 IDR and 102,000 IDR, respectively.

Table 6. The Minimum Number of WTP value Compositions

\begin{tabular}{|c|c|c|c|}
\hline \multicolumn{2}{|c|}{ Without electricity discounts offer } & \multicolumn{2}{c|}{$\begin{array}{c}\text { With electricity } \\
\text { discounts offer }\end{array}$} \\
\hline $\begin{array}{c}\text { Value (IDR) } \\
\text { /Month }\end{array}$ & Participants (\%) & $\begin{array}{c}\text { Value (IDR) } \\
\text { /Month }\end{array}$ & Participants (\%) \\
\hline 1,050 & 16 & 40,800 & 57 \\
\hline 3,500 & 43 & 51,000 & 18 \\
\hline 5,600 & 10 & 76,500 & 8 \\
\hline 7,000 & 11 & 102,000 & 5 \\
\hline 14,000 & 6 & & 259.087 .867 .520 \\
\hline Total/ Year & $22,987,609,914$ & Total/ Year & \\
\hline
\end{tabular}

\section{Conclusion}

Based on the calculation results through the financial model developed, both scenarios of resident based funding of sustainable landfill gas plant are good to go. They give a positive NPV values and good IRRs. The IRRs exceed the bank interest rate (MARR) that never more than $13.58 \%$. In this case, the IRR values are $13.91 \%$ and $13.77 \%$ for the investment scenario without electricity discounts and the investment scenario with electricity discounts, respectively. The minimum number of participant funding for without electricity discount scenario is $7 \%$ of total household of the City of Depok. While for the scenario with electricity discount, the number of participant is at least $51 \%$.

\section{Acknowledgment}

This work has been supported partially by PITTA B 2019 Grant funded by DRPM Universitas Indonesia under contract No. NKB0731/UN2.R3.1/HKP.05.00/2019.

\section{Reference}

Amigun, B. and Blottnitz, H.V. (2009). Capital cost prediction for biogas installations in Africa: Lang factor approach Authors. Environmental Progress and Sustainable Energy, 28, 134-142.

Amigun, B., Sigamoney, R., and Blottnitz H.V. (2008). Commercialisation of biofuel industry in Africa: A review. Renewable and Sustainable Energy Reviews, 12, 690-711. 
Ardiansyah, S. (2014). Analisis Model Pembangunan Pembangkit Listrik Tenaga Sampab Berkelanjutan. Unprinted Bachelor Thesis. Universitas Indonesia, Fakultas Teknik, Jakarta. In Indonesia language

BI (2016). Statistik. Ekonomi and Kenangan Indonesia. Jakarta: Bank Indonesia. In Indonesian language

BPS (2014). Depok Dalam Angka 2014-2015. Depok: Baand Pusat Statistik. In Indonesia language

Canada, J.R., Sullivan, W.G., Kulonda, D.J., and White, J.A. (2005). Capital Investment Analysis for Engineering and Management. $3^{\text {rd }}$ ed. Pearson-Prentice Hall, Upper Saddle River, NJ

DEN (2014). Energy Outlook 2014. Jakarta: Dewan Energi Nasional Republik Indonesia. In Indonesia language

DKP (2015). Mengenal Lebih Dekat TPA Cipayung Kota Depok. Depok: Dinas Kebersihan and Pertamanan Kota Depok. In Indonesian language

Dong, J., Chi, Y., Zou, D., Fu, C., Huang, Q., and Ni, M. (2014). Energy, environment, economy assessment of waste management systems from a life cycle perspective: Model development and case study. Applied Energy, 114, 400-408.

Duffy, Andiel P. (2016). Landfill Economics Part 2: Getting Down to Business. The Journal for MSW Professional

EMR (2013). Hand book of energy and economic statistic of Indonesia. Jakarta: Kementerian Energi and Sumber Daya Mineral.

ESDM (2013). Peraturan Mentri ESDM No. 44 Tabun 2015 Tentang Pembelian Tenaga Listrik oleh PT. PLN dari Pembangkit Listrik Berbasis Sampab Kota. Jakarta: Kementrian Energi and Sumber Daya Mineral. In Indonesian language

Farizal, Amalin, N., and Rachman, A. (2019). A new funding scheme for MSW management to support WtE program. International Conference on Advances in Energy Systems and Environmental Engineering (ASEE 19). Wroclaw, Poland

Farizal and Tammarar, E. (2018). Tipping fee determination to support the waste to energy concept at the city of Depok, Indonesia. Proceeding of Conference on Emerging Energy and Process Technology (CONCEPT) 7, UTM. https://doi.org/10.1051/e3sconf/20199001007

Johari, A., Ahmed, S.I., Hashim, H.,Alkali, H., and Ramli, M. (2012). Economic and environmental benefits of landfill gas from municipalsolid waste in Malaysia. Renewable and Sustainable Energy Reviews, 16, 2907-2912.

Indonesia Investments. (2019). https://www.indonesia-investments.com/culture/population/item67. Accessed 25/06/2019.

KEMENKEU (2009). PMK No. 21/PMK.01/2010 Tentang Pemberian Fasilitas Perpajakan and Kepabeanan. Jakarta: Kementrian Keuangan. In Indonesian language

KPU (2012). Pedoman Baban Konstruksi Bangunan and Rekayasa Sipil. Jakarta: Kementrian Pekerjaan Umum. In Indonesian language

Lu, W., Peng, Y.,Webster, C., and Zuo, J. 2015. Stakeholders' willingness to pay for enhanced construction waste management: A Hong Kong study. Renewable and Sustainable Energy Reviews, 47, 233-240.

Menikpura, S.N.M., Arun, J.S., and Bengtsson, M. (2014). Assessment of environmental and economic performance of Waste-to-Energy facilities in Thai cities. Renewable Energy, 86, 576-584.

Nevada Department of Taxation. (2010). Personal Property Manual 2011-2012. Division of Assessment Standards, Department of Taxation, Carson City.

Sudrajat, H. R.(2007). Mengelola Sampab Kota. Penebar Swadaya. Jakarta. In Indonesia language

Tasri A. and Susilawati, A. (2014). Selection among renewable energy alternatives based on a fuzzy analytic hierarchy process in Indonesia. Sustainable Energy Technologies and Assessments, 7, 34-44.

Tiess, G. and Mujiyanto, S. (2013). Secure energy supply in2025: Indonesia's needfor enenergy policy strategy. Energy policy, 61, 31-41.

Trisyanti, D. and Helmy, M. (2015). World waste to energy city summit. London, UK. INSWA

US EPA (2010). Landfill gas Energy Project Development Handbook, Landfill Methane Outreach Program. Washington, D.C: United States Environmental Protection Energy, Climate Change Division

US EPA (2015). Landfill gas Energy Project Development Handbook, Landfill Methane Outreach Program. Washington, D.C: United States Environmental Protection Energy, Climate Change Division.

Xin-gang, Z., Gui-wu, J., Ang, L., and Ling, W. (2015). Economic analysis of waste-to-energy industry in China. Waste Management, 48, 604-618.

Yazdani, R., Kieffer, J., Sananikone, K., and Augenstein, D. (2006). Final Tecbnical Progress Report - Full Scale Bioreactor Landfill for Carbon Sequestration and Greenhouse Emission Control. Yolo County Public Works, California. 